\title{
Reward Practice and Employees Performance Relationships: An Empirical Study of Tertiary Educational Institutions of Higher learning in Ghana
}

\author{
Mike Osei-Owusu ${ }^{1 *}$ Bismark Owusu Adu ${ }^{2}$ \\ Finance Office, Kwame Nkrumah University of Science and Technology (KNUST), Kumasi-Ghana \\ PMB, UPO, Kumasi, Ghana
}

\begin{abstract}
The study aimed to explore the management of performance from the perspective of rewards, which has received much attention due to the huge investments continually been put into tertiary education globally. This quantitative study argues that there is the need to determine the reward that goes with the expected performance and that, it is through the identification of rewards for a particular task that leads to an effective attainment of an equitable balance between contributions from both the employee and the organization respectively. This quantitative study used a canonical correlational method, through the use of a self-administered survey to investigate the relationship between intrinsic and extrinsic rewards to performance of educational institutions of higher learning in Ghana, focusing on both academic and non-academic employees. The findings from the analysis was statistically significant in defining relationship between intrinsic and extrinsic reward practices, and that both predicted performance of academic and non-academic employee of educational institutions of higher learning in Ghana. The findings therefore emphasize that employees of educational institution of higher learning in Ghana understand that when employees are psychologically satisfied intrinsically, then a social context is created for conducive teamwork and other discretionary behaviors be achieved extrinsically, for enhanced general working conditions at the work place.
\end{abstract}

Keywords: Intrinsic rewards; extrinsic rewards; education institutions; employee performance

DOI: $10.7176 / \mathrm{JEP} / 11-32-12$

Publication date: November $30^{\text {th }} 2020$

\section{Introduction and Problem Statement}

The cliché that the financial rewards, in other words, money via good salaries represents the most influential factor in motivating individuals into producing the expected high performance has lost a bit of attention (Parking, et al., 2004, cited in Dobre, 2013). The focus of attention has now shifted from only providing financial rewards to other non-financial factors that motivate employees in the form of rewards, social recognition and performance feedbacks (Dobre, 2013). To find out the effect of motivation on the performance of employees, there is the need to identify incentive schemes that links rewards to performance. Lut (2012) traced the contributions of psychological studies on how motivation within a company affects performance, results and work efficiency. The relationship Lut (2012) remarked exists within two variables. One is to make individuals to attach much importance to perceived difficult tasks, and the other having the intensity of motivation manipulated to really measure the effect of the impact of motivational interventions. It is through the identification of rewards for a particular task that would lead to the effectiveness of otherwise for the implementation of a reward System (Striteska, 2012).

Although the effect of reward on performance is not a phenomenon that is disputable, however there is the need for managers to embrace and accept the complexities of the effect of motivation which is influenced by individual, cultural, ethnic and historical factors; which must be managed and incorporated in defining reward systems and strategies to motivate employees, and to increase performance for both the employees and the organization as a whole (Khanifar, 2014). In the context of higher educational institutions in the in Ghana where even a formal performance evaluation system is not even in place to measure and appraise employee performance (Zakaria, 2014; Ohemeng, 2011; Ohemeng, 2009), then the linkage and possibly interdependence and its overall impact on organizational performance is an area worth undertaken studies. The study would therefore provide comprehensive study on the influence of reward on the performance of employees of educational institutions of higher learning in Ghana.

\section{Literature and Empirical Studies}

Rewards improves employees' performance (Edirisooriyaa, 2014; Güngör, 2011; James, et al., 2015; Khan, 2014; Otchere-Ankrah, 2013), which in turn leads to increased organizational performance (Furtado, et al., 2012; San, et al., 2012); as well as organizational effectiveness (Rowland \& Hall, 2014).

Empirically, Westover, et al. (2010) explored key work domains that impact worker job satisfaction and organizational commitment, which in turn impact long-term worker productivity and performance. They used the seventeen unique domains (work satisfaction, organizational commitment, performance appraisal quality, talent 
use by employer, recognition, intrusion on personal time, employee needs met, career development, opportunities to contribute, friendship, job security, anxiety with supervisor, autonomy, value congruence, supervisor competence, pay, benefits, long-term goals, passion) to determine whether differences in employee compensation and reward satisfaction existed at the workplace. The conclusions were that the seventeen statistically valid and reliable work domains that were applied in their study were relevant to understanding worker job satisfaction and organizational commitment, and highly explanatory models of worker motivation and job satisfaction.

Pregnolato, et al. (2017) in their empirical study, adopted quantitative approach and descriptive research design to investigate the significance of reward preferences and ideal combination of total reward elements on various demographic groups, including employees of different race, gender and age groups, within the context of employee retention. The study concluded on benefits, performance and recognition, remuneration, career, in that order to be significantly important in the total rewards composition; followed by career advancement, learning and work-life balance, with the least factor being learning opportunities.

Finally, Khan, et al. (2014) used the short form of the Minnesota Satisfaction Questionnaire (MSQ) survey to measure the level of satisfaction with intrinsic and extrinsic rewards, and its influence on the banking sector of Pakistan. They concluded that intrinsic and extrinsic rewards increase overall job satisfaction and performance of employees. Khan et al. (2013) further concluded that security, ability utilization, social service, variety, moral values, activity, and authority were significantly and positively correlated with self-reported employees' performance. On the other hand, recognition, supervision-human relations, advancement, and co-workers were found to be significantly and positively correlated with employees' performance.

\section{Method}

This quantitative research was based on other existing literature (Ibrar \& Khan, 2015; Aslam, et al., 2015) on impacts of rewards on performance. Currently there are 10 public universities, 8 professional public institutes/universities, 10 technical universities/polytechnics, 83 accredited private tertiary institutions, and all under the direct supervision of the National Council for Tertiary Education (NAB, 2019), with a total staff strength of 11,585 (NAB, 2019). Academic and non-academic/administrative senior membership employees were selected, excluding subordinate/supporting employees due to the fact that most of them are mainly unskilled and semiskilled staff, and not engaged much in the top management positions of the respective institutions. Stratified sampling was used to select three educational institutions of higher learning with equal representations of the various statuses of institutions from public/professional public, polytechnics/technical as well as private tertiary institutions.

Kwame Nkrumah University of Science and Technology (KNUST) originally established as Kumasi College of Technology by a Government Ordinance on 6th October, 1951, transformed into a full-fledged university by an Act of Parliament on 22nd August 1961. An act of Parliament (Act 559 of 1998) reverted from University of Science and Technology (February 1966) to its original name, Kwame Nkrumah University of Science and Technology in 2000. Currently, KNUST has a student population of just about 65,000 and staff population of 3,897 .

Kumasi Technical University was established in 1954 as Kumasi Technical Institute as a craft training institute, but subsequently under the supervision of the Ghana Education Service converted into a non-tertiary Polytechnic status offering technician diploma and sub- professional courses. It was further elevated into a tertiary institution (The Polytechnic Law, 1992 (PNDC L.321)) providing technical training in manufacturing, commerce, science and technology. The institutions status gained elevation by The Technical University Act 2016, (Act 922) into Kumasi Technical University providing higher education in engineering, applied arts, science technology based disciplines, technical and vocational training. Currently the institution has a student population of about 10,021 and staff population of 640 .

Christian Service University College began as a merger of two visions in January 1974 as an interdenominational, evangelical institution academic learning. The university is based on a main campus within Kumasi, and currently has a student population of just about 1904 and staff population of 161.

Within the ranks of the staff base of all the aforementioned tertiary institutions are; Professors, Senior Lecturers, Lecturers, Assistant Lecturers, qualified staff members of Professional Bodies or Institutions as well as Skilled and Non-Skilled Technicians whose contributions go a long way to determine the performance of the institution. The determination of the sample (for academics and non-academics) relative to the entire population, as well as the total sample size was from Krejcie \& Morgan (1970) formula. Therefore, the total sample size that questions were delivered for the study was 497, making up of 401 academics and 96 non-academics respectively. The data from the respondents from 283 out of 497 representing 56.94\% (202 academics and 81 non-academics) was screened and captured using SPSS to have the data organized and stored in readiness for statistical analysis.

\subsection{Measurement/Hypotheses}

The conceptual framework (see Figure 1) explained the relationships among the various variables of the in the 
formulation of the hypotheses on the assumption that reward system enables institutions strategies to motivate employees and increase performance (Khanifar, et al., 2014). The assumed causal relationship provided the conceptual framework in developing hypotheses for testing.

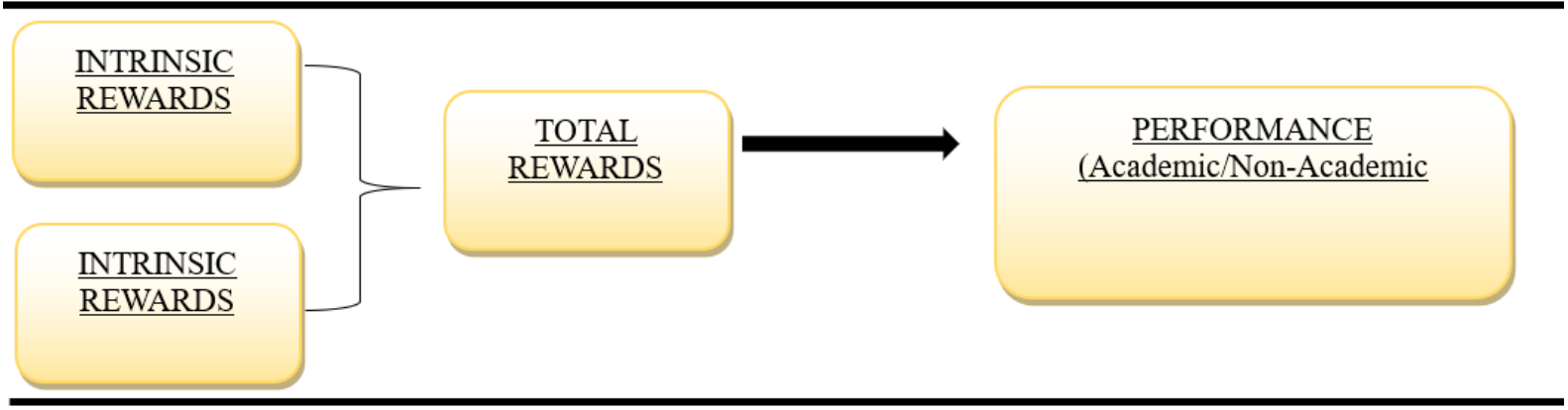

Figure 1. Framework for measurements and hypotheses (researcher's material)

H1: There is a statistically significant relationship between intrinsic reward practices and performance of employees of Higher Educational Institutions in Ghana.

$\mathrm{H} 2$ : There is a statistically significant relationship between extrinsic reward practices performance of employees of higher educational institutions in Ghana.

The measurement of rewards as independent variables was guided by studies of Güngör (2011); Pan, et al. (2015); Khan, et al. (2014) as produced in Table 1.

Table 1. List of Intrinsic and Extrinsic Rewards Factors

\begin{tabular}{l} 
Intrinsic Reward Variables \\
\hline Ability Utilization \\
Moral Values \\
Achievement \\
Creativity \\
Activity \\
Independence \\
Responsibility \\
Security \\
Authority \\
Social Services \\
Social Status \\
Variety
\end{tabular}

Extrinsic Reward Variables

Key performance indicators have become one of the mediums for the generation of the required information and data for measuring performances of organizations. Accordingly, "key performance indicators (KPI) represent a set of measures focusing on those aspects of organizational performance that are the most critical for the current and future success of the organization" (Parmenter, 2015, p.4). They are therefore expected to be the measure of performance in the study and thus, became the dependent variables. As the determination of key performance indicators for academic employees of educational institutions of higher learning could not be the same as nonacademics, it became necessary that different variables were used.

In this study, variables measured for proposed performance management indicators as dependent variables for academics were Teaching \& Supervision (Cadez, 2017; Ishak, et al., 2009; Masron, et al., 2011); Research \& Innovation (Banu, 2018; Ishak, et al., 2009; Masron, et al., 2011); Writing \& Publication (Ishak, et al., 2009); Consultancy (Abubakar, 2018; Masron, et al., 2011) as well as Services (Macdonald, et al., 2012). On the other hand variable for the non-academics was measured as Professional Competency (Alexandra \& Brad, 2015; Madukoma \& Opeke, 2013); Strategic Leadership/Integrity/Confidentiality (Tasić, et al., 2018; Hanover, 2010); Administrative Procedures (Iveta, 2012); Management Skills \& Productivity (Velimirović, et al., 2012; Hanover, 2010); Initiation \& Accountability (Hanover, 2010; Madukoma \& Opeke, 2013) as well as Services (Macdonald, et al., 2012). Responses to statements relating to key operational indicators for both academic and non-academics were measured on a five-point Likert scale from very important to not very important; whilst measures for key performance indicators measured from very effective to not very effective.

\subsection{Statistical Technique}

Canonical correlation (Hotelling, 1936) is a suitable methodology for multiple dependent (criterion) and multiple independent (predictor) analysis (Daniel Shim \& Lee, 2003; Enginyurt, 2016; Joo \& Nimon, 2014; Joo, et al., 2014), was used to determine which individual independent variables would be a significant predictor of the dependent variable of performance. The process enables a linear combination of criterion variables that is 
maximally correlated with predictor variables (Canonical Function or pair 1) was determined to pair linear combinations having the largest correlation to all pairs uncorrelated with the initially selected pair (Canonical Function or Pair 2). The process continues until the maximum number of canonical functions (pairs) is equal to the fewest number of variables in the sets, to form the canonical functions (pairs). The significance of association of an acceptable lower bounds of loadings lies between 0.30 and 0.50 (Bech, 2012). In the study, the significance of association with the loadings is set at 0.45 (Prera, et al., 2012; Yu, et al., 2017).

\subsection{Results}

4.1.1 Relationship between Intrinsic Rewards and Performance (Academic)

Although the canonical correlation analysis (Table 2) produced five functions, however four functions cumulatively explained about $94.86 \%$ with squared canonical correlations of $0.11,0.100,0.082$ and 0.039 respectively, and deemed significant to be analysed.

Table 2. Canonical Correlation for the Functions

\begin{tabular}{llllll}
\hline Root Number & Eigenvalue & Pct. & Cum. Pct. & Canon Cor. & Sq. Cor \\
\hline \hline 1 & 0.123 & 32.057 & 32.057 & 0.331 & 0.109 \\
2 & 0.111 & 29.061 & 61.118 & 0.316 & 0.100 \\
3 & 0.089 & 23.191 & 84.310 & 0.285 & 0.081 \\
4 & 0.040 & 10.546 & 94.856 & 0.197 & 0.038 \\
5 & 0.019 & 5.143 & 100 & 0.139 & 0.019 \\
\hline \hline
\end{tabular}

Table 3. Canonical Solution for Intrinsic Rewards and performance of Academic employees of Educational Institutions of Higher Learning in Ghana for Functions 1-5

\begin{tabular}{|c|c|c|c|c|c|c|c|c|c|c|}
\hline \multirow[b]{2}{*}{ Variable } & \multicolumn{2}{|c|}{ FUNCTION 1} & \multicolumn{2}{|c|}{ FUNCTION 2} & \multicolumn{2}{|c|}{ FUNCTION 3} & \multicolumn{2}{|c|}{ FUNCTION 4} & \multicolumn{2}{|c|}{ FUNCTION 5} \\
\hline & CO-EFF & $\mathrm{RS}$ & CO-EFF & $\mathrm{RS}$ & CO-EFF & RS & CO-EFF & RS & CO-EFF & RS \\
\hline Depenents: & & & & & & & & & & \\
\hline $\begin{array}{l}\text { Teaching \& Supervision } \\
\text { Research \& Innovation } \\
\text { Writing \& Publication } \\
\text { Consultancy } \\
\text { Services }\end{array}$ & -0.784 & -0.712 & 1.093 & 0.596 & -0.934 & -0.967 & -0.281 & -0.533 & $\begin{array}{l}-0.312 \\
-0.022 \\
-0.957\end{array}$ & $\begin{array}{l}-0.477 \\
-0.485 \\
-0.824\end{array}$ \\
\hline Independents: & & & & & & & & & & \\
\hline $\begin{array}{l}\text { Ability Utilization } \\
\text { Moral Values } \\
\text { Achievement }\end{array}$ & 0.565 & 0.546 & -0.541 & -0.503 & -0.477 & -0.485 & & & & \\
\hline $\begin{array}{l}\text { Creativity } \\
\text { Activity } \\
\text { Independence }\end{array}$ & & & $\begin{array}{l}-0.555 \\
-0.309\end{array}$ & $\begin{array}{l}-0.528 \\
-0.458\end{array}$ & & & & & 0.298 & 0.474 \\
\hline $\begin{array}{l}\text { Responsibility } \\
\text { Security } \\
\text { Authority } \\
\text { Social Services }\end{array}$ & & & & & -0.690 & -0.578 & & & 0.455 & 0.620 \\
\hline $\begin{array}{l}\text { Social Status } \\
\text { Variety }\end{array}$ & & & & & & & $\begin{array}{l}0.647 \\
0.413\end{array}$ & $\begin{array}{l}0.589 \\
0.475\end{array}$ & 0.329 & 0.535 \\
\hline
\end{tabular}

\section{Co-eff: Standardized canonical function coefficient, Rs: Structured coefficient (correlations functions and} variables) greater than $|0.45|$ only shown

Results (Table 3 ) produced the standardized canonical function coefficients and structure coefficients for five functions. Regarding Function 1 coefficients together with structured coefficient, the relevant performance variable was principally Teaching \& Supervision. Furthermore, Research \& Innovation \& Consultancy showed an inverse relationship with Function 1 whiles the other criteria indicated a positive relationship to Function 1. Compared with the predictor variable set in Function 1, only Achievement was the key contributor. Also, Moral Values, Activity, Responsibility and Variety were negatively related to the function while the rest were positively related to the Function 1. For Function 2, the results suggest that the measure variable of relevance was Research \& Innovation which was positively related. Further, Teaching \& Supervision and Services were negatively related, while the other variables related positively to the Function 2. Ability Utilization, Activity and Independence were the intrinsic predictors on function 2, although negative.

On Function 3, Consultancy was significant, and for the intrinsic variables were Achievement and Responsibility as the main significant variables. Function 4 had Research \& Innovation and Services as the performance variables whiles Social Status and Variety reported the structured coefficients greater than $|0.45|$. Considering Function 5, Teaching \& Supervision, Research \& Innovation and Writing \& Publication were the main contributors of function 4, and correlated significantly with the following intrinsic variable Activity, Security 
and Social Status. Therefore, some of the intrinsic rewards practices predicted performance of academic employees of educational institutions of higher learning in Ghana.

4.1.2 Relationship between Intrinsic Rewards and Performance (Non-Academic)

The canonical correlation analysis (Table 4) on twelve intrinsic rewards practices variables as predictors of the five non-academic performance variables yielded six functions with squared canonical correlations of $0.430,0.302$, $0.258,0.150,0.090$ and 0.049 for each successive function respectively.

Table 4. Canonical Correlation for the Functions

\begin{tabular}{lrrrrr}
\hline Root Number & Eigenvalue & Pct. & Cum. Pct. & Canon Cor. & Sq. Cor \\
\hline 1 & 0.755 & 40.505 & 40.505 & 0.656 & 0.430 \\
2 & 0.434 & 23.274 & 63.779 & 0.550 & 0.302 \\
3 & 0.349 & 18.707 & 82.486 & 0.508 & 0.258 \\
4 & 0.176 & 9.450 & 91.936 & 0.387 & 0.150 \\
5 & 0.099 & 5.323 & 97.259 & 0.300 & 0.090 \\
6 & 0.051 & 2.741 & 100.000 & 0.220 & 0.049 \\
\hline
\end{tabular}

Table 5. Canonical Solution for Intrinsic Rewards and performance of Academic employees of Educational Institutions of Higher Learning in Ghana for Functions 1-5

\begin{tabular}{|c|c|c|c|c|c|c|c|c|c|c|c|c|}
\hline \multirow[b]{2}{*}{ Variable } & \multicolumn{2}{|c|}{ FUNCTION 1} & \multicolumn{2}{|c|}{ FUNCTION 2} & \multicolumn{2}{|c|}{ FUNCTION 3} & \multicolumn{2}{|c|}{ FUNCTION 4} & \multicolumn{2}{|c|}{ FUNCTION 5} & \multicolumn{2}{|c|}{ FUNCTION 6} \\
\hline & $\begin{array}{l}\mathrm{CO}- \\
\mathrm{EFF}\end{array}$ & RS & $\begin{array}{l}\mathrm{CO}- \\
\mathrm{EFF}\end{array}$ & $\mathrm{RS}$ & $\begin{array}{l}\mathrm{CO}- \\
\mathrm{EFF}\end{array}$ & RS & $\begin{array}{l}\mathrm{CO}- \\
\mathrm{EFF}\end{array}$ & RS & $\begin{array}{l}\mathrm{CO}- \\
\mathrm{EFF}\end{array}$ & RS & $\begin{array}{l}\mathrm{CO}- \\
\mathrm{EFF}\end{array}$ & $\mathrm{RS}$ \\
\hline \multicolumn{13}{|l|}{ Dependents: } \\
\hline $\begin{array}{l}\text { Professional Competence } \\
\text { Strategic leadership/ }\end{array}$ & 0.621 & 0.787 & & & 0.643 & 0.471 & & & & & & \\
\hline $\begin{array}{l}\text { Integrity/Confidentiality } \\
\text { Administrative }\end{array}$ & -0.320 & 0.617 & -1.115 & -0.694 & & & & & & & & \\
\hline $\begin{array}{l}\text { Procedures } \\
\text { Management Skills \& }\end{array}$ & & & -0.483 & -0.536 & & & & & & & 0.567 & 0.724 \\
\hline $\begin{array}{l}\text { Productivity } \\
\text { Initiation \& }\end{array}$ & 0.499 & 0.781 & & & & & & & & & 0.583 & 0.549 \\
\hline Accountability & 0.256 & 0.713 & & & -1.100 & -0.486 & & & & & & \\
\hline $\begin{array}{l}\text { Services } \\
\text { Independents: }\end{array}$ & 0.318 & 0.519 & & & & & & & & & & \\
\hline Ability Utilization & 0.730 & 0.596 & & & & & & & & & & \\
\hline Moral Values & & & -0.966 & -0.551 & & & & & & & & \\
\hline Achievement & & & & & & & & & 0.630 & 0.544 & 0.404 & 0.472 \\
\hline Creativity & & & & & & & & & & & -0.401 & -0.577 \\
\hline Activity & & & & & & & & & & & & \\
\hline Independence & 0.321 & 0.462 & & & & & & & & & & \\
\hline Responsibility & & & & & & & & & & & & \\
\hline Security & & & & & & & & & & & & \\
\hline Authority & 0.395 & 0.462 & & & & & & & & & & \\
\hline Social Services & & & & & & & & & -0.687 & -0.655 & & \\
\hline Social Status & 0.340 & 0.488 & & & & & -0.612 & -0.590 & & & & \\
\hline Variety & 0.377 & 0.510 & & & & & -0.142 & -0.462 & & & & \\
\hline
\end{tabular}

The result (Table 5) produced six functional standardized canonical function coefficients. Observations made on Function 1 coefficients with the structured coefficient, the relevant non-academic performance variables were Professional Competence, Strategic Leadership/ Integrity/Confidentiality, Management Skills \& Productivity, Initiation \& Accountability, Services. Furthermore, Ability of Utilization, Independence, Authority, Social Status and Variety were the primary contributors. All the variables were positively related to Function 1 except for Achievement. For Function 2, the results suggest that the criterion variable of relevance was Strategic Leadership/ Integrity/Confidentiality and Administrative Procedures, and was also inversely related to this function, whiles Moral Values was only the predictor variable. On Function 3, Professional Competence as well as Initiation \& Accountability were the criterion variables for non-academic, and none of the intrinsic reward practices were main contributors. Function 4, none of the performance variables was significant contributor, although Social Status and Variety were the major intrinsic reward contributors to the function whiles Achievement and Social Services were the key intrinsic reward contributors. With regards to Function 6, Administrative Procedures and Management Skills \& Productivity were the main contributors' whiles Achievement and Creativity for intrinsic reward practices were significant contributors. From the above analysis some of the intrinsic rewards practices predicted performance of non-academic employees of educational institutions of higher learning in Ghana.

4.2.1 Relationship between Extrinsic Reward Practices and Performance (Academic)

The outcomes (Table 6) of the canonical correlation analysis formed five functions, where four functions cumulatively explained about $94.63 \%$ with corresponding squared canonical correlations of $0.123,0.057,0.042$ and 0.026 respectively. 


\begin{tabular}{lrrrrr}
\hline \multicolumn{5}{c}{ Table 6. Canonical Correlation for the Functions } \\
\hline Root Number & Eigenvalue & Pct. & Cum. Pct. & Canon Cor. & Sq. Cor \\
\hline & & & & & \\
1 & 0.140 & 49.268 & 49.268 & 0.351 & 0.123 \\
2 & 0.059 & 20.94 & 70.217 & 0.237 & 0.056 \\
3 & 0.043 & 15.196 & 85.414 & 0.203 & 0.041 \\
4 & 0.026 & 9.212 & 94.627 & 0.160 & 0.025 \\
5 & 0.015 & 5.372 & 100 & 0.122 & 0.015 \\
\hline
\end{tabular}

Table 7. Canonical Solution for Extrinsic Rewards and Performance of Academic Employees of Educational Institutions of Higher Learning in Ghana for functions 1-5

\begin{tabular}{|c|c|c|c|c|c|c|c|c|c|c|}
\hline \multirow[b]{2}{*}{ Variable } & \multicolumn{2}{|c|}{ FUNCTION 1} & \multicolumn{2}{|c|}{ FUNCTION 2} & \multicolumn{2}{|c|}{ FUNCTION 3} & \multicolumn{2}{|c|}{ FUNCTION 4} & \multicolumn{2}{|c|}{ FUNCTION 5} \\
\hline & CO-EFF & $\mathrm{RS}$ & CO-EFF & $\mathrm{RS}$ & CO-EFF & $\mathrm{RS}$ & CO-EFF & $\mathrm{RS}$ & CO-EFF & $\mathrm{RS}$ \\
\hline \multicolumn{11}{|l|}{ Depenents: } \\
\hline Teaching \& Supervision & -0.424 & -0.512 & & & 0.678 & 0.456 & & & -0.456 & -0.631 \\
\hline Research \& Innovation & & & & & -1.037 & -0.429 & & & -0.294 & -0.501 \\
\hline Writing \& Publication & & & 0.849 & 0.454 & & & -0.752 & -0.781 & & \\
\hline Consultancy & & & -0.915 & -0.653 & & & -0.289 & -0.572 & & \\
\hline \multicolumn{11}{|l|}{ Services } \\
\hline \multicolumn{11}{|l|}{ Independents: } \\
\hline Co-workers & & & -0.955 & -0.699 & & & & & & \\
\hline \multicolumn{11}{|l|}{ Recognition } \\
\hline Advancement & 0.826 & 0.730 & & & & & & & & \\
\hline Company Policies & & & & & 0.799 & 0.774 & & & -0.519 & -0.452 \\
\hline \multicolumn{11}{|l|}{ Compensation } \\
\hline Working Conditions & 0.304 & 0.452 & & & 0.520 & 0.518 & & & & \\
\hline \multicolumn{11}{|l|}{ Supervision (Human Relation) } \\
\hline Supervision (Technical) & & & & & & & & & & \\
\hline
\end{tabular}

\section{Co-eff: Standardized canonical function coefficient, Rs: Structured coefficient (correlations functions and variables) greater than $|0.45|$ only shown}

Table 7 produced five functional standardized canonical function coefficients. With regards to Function 1, the pertinent performance variables were essentially Teaching \& Supervision. Besides, Research \& Innovation, Writing \& Publication and Consultancy showed an inverse relationship with Function 1, whiles Services indicated a positive relationship. With regards to the predictor variable set in Function 1, Advancement and Working Conditions were the key contributors.

For Function 2, the variables of relevance were Research \& Innovation as well as Writing \& Publication. The performance variables positively related to this function were Teaching \& supervision, Research \& Innovation and Writing \& Publication; with Consultancy \& Services negatively related. Also the intrinsic predictor on function 2 was Co-workers. With regards to Function 3, Teaching \& Supervision was significant while for the extrinsic variables Company Policies and Working Conditions were the pertinent significant variables. For Function 4, Writing \& Publication and Consultancy as the performance variables with all extrinsic variables reported structured coefficients less than $|0.45|$. From Function 5, Teaching \& Supervision, Research \& Innovation and Services were the main contributors of this function, having correlated significantly with Company Policies as extrinsic variable. Therefore, some of the extrinsic rewards practices predicted performance of academic employees of educational institutions of higher learning in Ghana.

4.2.1 Relationship between Extrinsic Reward Practices and Performance (Non-Academic)

The analysis (Table 8 ) yielded three functions which explained about $88.713 \%$ of the multivariate shared relationship with squared canonical correlations of $0.284,0.14672$, and 0.091 for the first three functions respectively.

Table 8. Canonical Correlation for the Functions

\begin{tabular}{lrrrrr}
\hline Root Number & Eigenvalue & Pct. & Cum. Pct. & Canon Cor. & Sq. Cor \\
1 & 0.398 & 52.641 & 52.641 & 0.533 & 0.284 \\
2 & 0.171 & 22.735 & 75.376 & 0.383 & 0.146 \\
3 & 0.100 & 13.337 & 88.713 & 0.302 & 0.091 \\
4 & 0.052 & 6.922 & 95.636 & 0.223 & 0.049 \\
5 & 0.025 & 3.339 & 98.975 & 0.156 & 0.024 \\
6 & 0.007 & 1.024 & 100 & 0.087 & 0.007 \\
\hline
\end{tabular}


Table 8. Canonical Solution for Extrinsic Rewards and Performance of Non-Academic Employees of Educational Institutions of Higher Learning in Ghana for functions 1-3

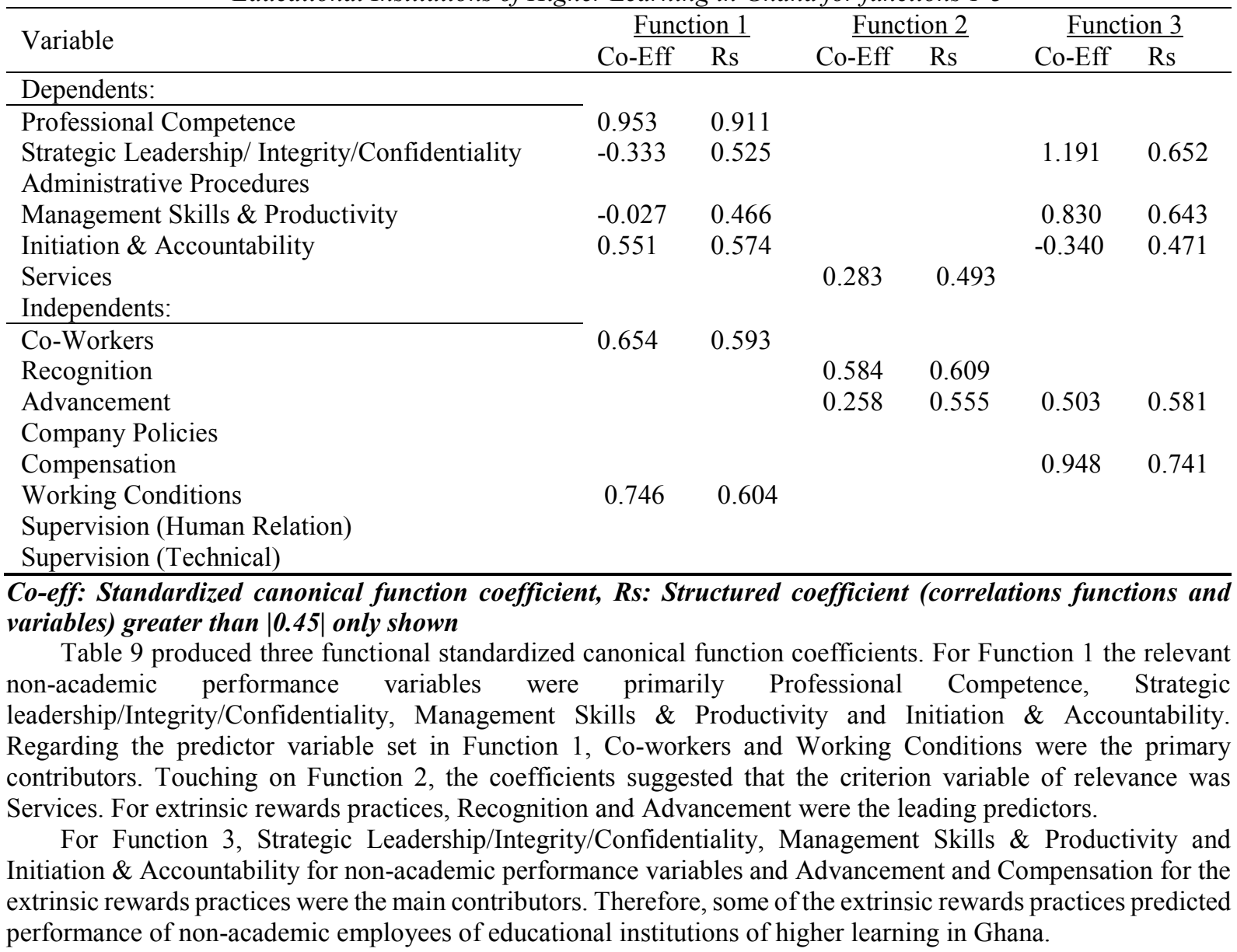

\subsection{Discussion}

Based on the findings from the academic perspective, the statistical significance test for the full canonical correlation analysis was not substantial in defining relationship between intrinsic reward practices and performance (Wilks's $\lambda$ of $0.69327, F(60,865.38)=0.178, p>.05$ ); and extrinsic reward practices (Wilks's $\lambda$ of $0.7607, F(40,826.63)=1.3383, p>.05)$ respectively, therefore a canonical correlation function analysis was conducted. Firstly, all the performance indicators were relevant in describing performance for intrinsic, and all but Research \& Innovation for extrinsic rewards (See Appendix A \& B). Further all the reward items had significantly positive relationship with performance, leading to rejection of null hypothesis $\mathrm{H} 1$ and $\mathrm{H} 2$ for intrinsic and extrinsic rewards respectively.

From the non-academic perspective, the statistical significance test for the full canonical correlation analysis was statistically significant in defining relationship between intrinsic reward practices and performance (Wilks's $\lambda$ of $1.56997, F(72,348.56)=0.21693, p<.05)$; but statistically inadequate in describing relationship between extrinsic reward practices and performance (Wilks's $\lambda$ of $0.5099, \mathrm{~F}(48,333.73)=1.02002, p>.05)$. Also, all the performance indicators were relevant in describing performance for both intrinsic and extrinsic rewards (See Appendix A \& B). Exhibiting same findings as the academics, all the reward items had significantly positive relationship with performance, leading to rejection of null hypothesis $\mathrm{H} 1$ and $\mathrm{H} 2$ for intrinsic and extrinsic rewards respectively.

\subsection{Conclusions}

The study provided evidence with the positive relationship between reward practices and performance of employees of educational institution of higher learning in Ghana with the conclusion that dissatisfaction with rewards lowers employee commitment to their jobs. The findings therefore emphasize that employees understand the principal benefits of rewards as well as the relative significance of the different aspects of the reward propositions. Further when employees are psychologically satisfied intrinsically, then a social context is created for conducive teamwork and other discretionary behaviors be achieved extrinsically, for enhanced general working conditions at the work place. The implication here is that management of the respective institutions need to build 
a reward package that is both internally and externally competitive to include both monetary and non- financial rewards. It therefore imperative that putting a proper performance related reward system in place thus becomes the grounds for institutions to achieve its set goals, objectives and strategies.

\section{References}

Abubakar, A., Hilman, H., \& Kaliappen, N. (2018). New tools for measuring global academic performance. SAGE Open, 8(3), 1-10.

Alexandra, T. E., \& Brad, L. (2015). Competency assessment using key performance indicators. International Journal of Academic Research in Business and Social Sciences. The Bucharest University of Economic Studies, 5(6), 75-86.

Banu, G. S. (2018). Measuring innovation using key performance indicators. Procedia Manufacturing, 22, 906911.

Bech, P. (2012). Rating scales for psychopathology, health status and quality of life: A compendium on documentation in accordance with the DSM-III-R and WHO systems. Heidelberg: Springer Science \& Business Media.

Cadez, S., Dimovski, V., \& Zaman Groff, M. (2017). Research, teaching and performance evaluation in academia: the salience of quality. Studies in Higher Education, 42(8), 1455-1473.

Daniel Shim, E., \& Lee, J. (2003). A canonical correlation analysis of CEO compensation and corporate performance in the service industry. Review of Accounting and Finance, 2(3), 72-90.

Dobre, O. I. (2013). Employee motivation and organizational performance. Review of Applied Socio- Economic Research, 5(1), 53-60.

Edirisooriyaa, W. A. (2014). Impact of rewards on employee performance: With special reference to ElectriCo. In Proceedings of the 3rd International Conference on Management and Economics (26), 312-318.

Enginyurt, O., Cankaya, S., Aksay, K., Tunc, T., Koc, B., Bas, O., \& Ozer, E. (2016). Relationship between organisational commitment and burnout syndrome: a canonical correlation approach. Australian Health Review, 40(2), 181-187.

Furtado, F., Aquino, G., \& Meira, S. (2012). Improving organizational performance through reward systems. In Business Dynamics in the 21st Century. InTech. Vol.1.

Güngör, P. (2011). The relationship between reward management system and employee performance with the mediating role of motivation: A quantitative study on global banks. Procedia-Social and Behavioral Sciences, $24,1510-1520$.

Hanover Research. (2010). Key performance indicators for administrative support units. Hanover Research. Retrieved on $01 / 07 / 2020$ at:

https://books.google.com.gh/books/about/Key_Performance_Indicators_for_Administr.hml?id=cFViAQAACAJ \&redir_esc $=$ y

Ibrar, M., \& Khan, O. (2015). The impact of reward on employee performance (a case study of Malakand Private School). International Letters of Social and Humanistic Sciences, 52, 95-103.

Ishak, M. M., Suhaida, M. S., \& Yuzainee, M. Y. (2009). Performance measurement indicators for academic staff in Malaysia private higher education institutions: A case study in UNITEN. In PMA Conference 2009.

Iveta, G. (2012). Human resources key performance indicators. Journal of Competitiveness, 4(1), 117-128.

James, O. E., Ella, R., Nkamare, S. E., Lukpata, F. E., Uwa, S. L., \& Mbum, P. A. (2015). Effect of reward system among health care workers performance: A case study of university of Calabar teaching hospital Calabar. Nigeria. Journal of Hospital Administration, 4(3), 45-53.

Joo, B. K., \& Nimon, K. (2014). Two of a kind? A canonical correlational study of transformational leadership and authentic leadership. European Journal of Training and Development, 38(6), 570-587.

Joo, B. K., Yang, B., \& McLean, G. N. (2014). Employee creativity: The effects of perceived learning culture, leader-member exchange quality, job autonomy, and proactivity. Human Resource Development International, 17(3), 297-317.

Khan, Z., Karim, N., \& Jan, S. U. (2014). Role of performance based reward system in improving employee's productivity and job satisfaction: Analysis of government and private sector of Peshawar. City University Research Journal, 4(1), 80-87.

Khanifar, H., Rahmati, M. H., \& Fakhrabadi, M. K. (2014). Recognition of strategic reward systems and incentives influencing employees. International Journal of Modern Management and Foresight, 1(5), 146-155.

Krejcie, R. V., \& Morgan, D. W. (1970). Determining sample size for research activities. Educational and psychological measurement, 30(3), 607-610.

Lut, D. M. (2012). Connection between job motivation, job satisfaction and work performance in Romanian trade enterprises. Economics and Applied Informatics, 18(3), 45-50.

Masron, T. A., Ahmad, Z., \& Rahim, N. B. (2012). Key performance indicators vs key intangible performance among academic staff: A case study of a public university in Malaysia. Procedia-Social and Behavioral 
Sciences, 56, 494-503.

Macdonald, B., Rust, C., Thrift, C., \& Swanson, D. (2012). Measuring the performance and impact of community indicators systems: Insights on frameworks and examples of key performance indicators. International Institute for Sustainable Development, Canada. Retrieved on 29/12/2018 at: https://www.iisd.org/sites/default/files/publications/measuring_performance_communtiy_indicators.pdf

Madukoma, E. (2013). Information use and job performance of senior non-academic staff in Nigerian Universities. Library Philosophy and Practice, 01-08.

National Accreditation Board (NAB), (2019). Number of Accredited tertiary institutions in Ghana per category as at January, 2018. Retrieved on 5/06/2020 at: http://www.nab.gov.gh/news1/414-accredited-published-tertiary institutions-as-at-august-2016-summary

Ohemeng, F. L. K. (2011). Institutionalizing the PM System in public organizations in Ghana: Chasing a mirage?. Public Performance \& Management Review, 34(4), 467-488.

Ohemeng, K. L. F. (2009). Constraints in the implementation of PM Systems in developing countries. The Ghanaian Case. International Journal of Cross Cultural Management, 9(1), 109-132.

Otchere-Ankrah, B. (2015). Managing organisational change: The experience of Driver and Vehicle Licensing Authority (DVLA) of Ghana. International Public Management Review, 16(1), 1-22.

Pan, B., Shen, X., Liu, L., Yang, Y., \& Wang, L. (2015). Factors associated with job satisfaction among university teachers in Northeastern region of China: A cross-sectional study. International Journal of Environmental Research and Public Health, 12(10), 12761-12775.

Parmenter, D. (2015). Key performance indicators: developing, implementing, and using winning KPIs. John Wiley \& Sons.

Parkin, S., Johnson, A., Buckland, H., \& White, E. (2004). Learning and skills for sustainable development: Developing a sustainability literate society. Higher Education Partnership for Sustainability (HEPS), London.

Pregnolato, M., Bussin, M. H., \& Schlechter, A. F. (2017). Total rewards that retain: A study of demographic preferences. SA Journal of Human Resource Management, 15(1), 1-10.

Prera, A. J., Grimsrud, K. M., Thacher, J. A., McCollum, D. W., \& Berrens, R. P. (2014). Using canonical correlation analysis to identify environmental attitude groups: Considerations for national forest planning in the Southwestern US. Environmental Management, 54(4), 756-767.

Rowland, C., \& Hall, R. (2014). Management learning, performance and reward: theory and practice revisited. Journal of Management Development, 33(4), 342-35.

San, O., Theen, Y., \& Heng, T. (2012). The reward strategy and performance measurement (evidence from Malaysian insurance companies). International Journal of Business, Humanities and Technology, 2(1), 211223.

Striteska, M. (2012). Key features of strategic PM Systems in manufacturing companies. Procedia-Social and Behavioral Sciences, 58, 1103-1110.

Tasić, N., Đurić, Ž., Malešević, D., Maksimović, R., \& Radaković, N. (2018). Automation of process performance management in a Company. Tehnički vjesnik, 25(2), 565-572.

Westover, J. H., Westover, A. R., \& Westover, L. A. (2010). Enhancing long-term worker productivity and performance: The connection of key work domains to job satisfaction and organizational commitment. International Journal of Productivity and Performance Management, 59(4), 372-387.

Yu, N., Zhang, Q., Zhang, L., He, T., Liu, Q., \& Zhang, S. (2017). Canonical correlation analysis (CCA) of anthropometric parameters and physical activities with blood lipids. Lipids in Health and Disease, 16(1), 236230.

Zakaria, H. B. (2014). Is performance management in Ghana's public service a mirage? Retrieved on 10/07/2020 at: http://fairwages.gov.gh/Slideshow-News/is-performance- management-in-ghanas-public-service-a mirage/All-Pages.html 


\section{Appendices}

Appendix A. Relationship between Intrinsic Reward Practices and Performance (Academics and Non-

\begin{tabular}{|c|c|c|c|c|c|c|c|c|c|c|c|}
\hline VARIABLES & $\begin{array}{c}\text { Co- } \\
\text { workers }\end{array}$ & $\begin{array}{l}\text { Recog- } \\
\text { nition }\end{array}$ & $\begin{array}{l}\text { Advance- } \\
\text { ment }\end{array}$ & $\begin{array}{l}\text { Compe- } \\
\text { nsation }\end{array}$ & $\begin{array}{l}\text { Working } \\
\text { Conditions }\end{array}$ & $\begin{array}{l}\text { Supervision } \\
\text { (Human } \\
\text { Relation) } \\
\end{array}$ & $\begin{array}{l}\text { Supervision } \\
\text { (Technical) }\end{array}$ & Security & $\begin{array}{l}\text { Auth- } \\
\text { eritx }\end{array}$ & $\begin{array}{c}\text { Social } \\
\text { Services }\end{array}$ & $\begin{array}{l}\text { Social } \\
\text { Status }\end{array}$ \\
\hline \multicolumn{12}{|l|}{$\begin{array}{l}\text { DEPENENTS } \\
\text { (ACADEMICS): }\end{array}$} \\
\hline Teaching \& & + ve & $+\mathrm{ve}$ & + ve & + ve & + ve & $+\mathrm{ve}$ & + ve & $+\mathrm{ve}$ & + ve & + ve & + ve \\
\hline $\begin{array}{l}\text { Research \& } \\
\text { Innovation }\end{array}$ & $+\mathrm{ve}$ & + ve & $+\mathrm{ve}$ & + ve & $+\mathrm{ve}$ & $+\mathrm{ve}$ & + ve & $+\mathrm{ve}$ & $+\mathrm{ve}$ & $+\mathrm{ve}$ & + ve \\
\hline $\begin{array}{l}\text { Writing \& } \\
\text { Publication }\end{array}$ & $+\mathrm{ve}$ & + ve & + ve & $+\mathrm{ve}$ & + ve & + ve & $+\mathrm{ve}$ & + ve & + ve & + ve & + ve \\
\hline Consultancy & $+\mathrm{ve}$ & + ve & $+\mathrm{ve}$ & $+\mathrm{ve}$ & $+\mathrm{ve}$ & $+\mathrm{ve}$ & $+\mathrm{ve}$ & + ve & + ve & $+\mathrm{ve}$ & + ve \\
\hline Services & $+\mathrm{ve}$ & + ve & $+\mathrm{ve}$ & $+\mathrm{ve}$ & $+\mathrm{ve}$ & $+\mathrm{ve}$ & + ve & + ve & + ve & $+\mathrm{ve}$ & + ve \\
\hline \multicolumn{12}{|l|}{$\begin{array}{l}\text { DEPENDENTS } \\
\text { (NON- } \\
\text { ACADEMIICS): }\end{array}$} \\
\hline $\begin{array}{l}\text { Professional } \\
\text { Competence }\end{array}$ & $+\mathrm{ve}$ & + ve & + ve & + ve & + ve & $+\mathrm{ve}$ & + ve & + ve & + ve & $+\mathrm{ve}$ & + ve \\
\hline \multicolumn{12}{|l|}{ Strategic } \\
\hline $\begin{array}{l}\text { Integrity/Confidenti } \\
\text { ality }\end{array}$ & $+\mathrm{ve}$ & + ve & + ve & + ve & + ve & + ve & $+\mathrm{ve}$ & $+\mathrm{ve}$ & + ve & + ve & + ve \\
\hline $\begin{array}{l}\text { Administrative } \\
\text { Procedures }\end{array}$ & + ve & + ve & + ve & + ve & $+\mathrm{ve}$ & + ve & $+\mathrm{ve}$ & + ve & + ve & + ve & + ve \\
\hline $\begin{array}{l}\text { Management Skills } \\
\text { \& Productivity }\end{array}$ & + ve & + ve & + ve & + ve & + ve & + ve & + ve & $+\mathrm{ve}$ & + ve & + ve & + ve \\
\hline $\begin{array}{l}\text { Initiation \& } \\
\text { Accountability }\end{array}$ & + ve & + ve & $+\mathrm{ve}$ & + ve & + ve & + ve & $+\mathrm{ve}$ & $+\mathrm{ve}$ & + ve & + ve & + ve \\
\hline Services & + ve & + ve & + ve & + ve & $+\mathrm{ve}$ & $+\mathrm{ve}$ & $+\mathrm{ve}$ & $+\mathrm{ve}$ & + ve & $+\mathrm{ve}$ & + ve \\
\hline
\end{tabular}

Appendix B. Relationship between Extrinsic Reward Practices and Performance (Academics and NonAcademics)

\begin{tabular}{|c|c|c|c|c|c|c|c|c|}
\hline VARIABLES & $\begin{array}{c}\text { Co- } \\
\text { workers }\end{array}$ & $\begin{array}{l}\text { Recog- } \\
\text { nition }\end{array}$ & $\begin{array}{l}\text { Advanc- } \\
\text { ement }\end{array}$ & $\begin{array}{l}\text { Company } \\
\text { Policies }\end{array}$ & $\begin{array}{l}\text { Compe- } \\
\text { nsation }\end{array}$ & $\begin{array}{l}\text { Working } \\
\text { Conditions }\end{array}$ & $\begin{array}{c}\text { Supervision } \\
\text { (Human } \\
\text { Relation) } \\
\end{array}$ & $\begin{array}{l}\text { Supervision } \\
\text { (Technical) }\end{array}$ \\
\hline \multicolumn{9}{|l|}{$\begin{array}{l}\text { DEPENENTS } \\
\text { (ACADEMICS): }\end{array}$} \\
\hline Teaching \& Supervision & + ve & + ve & + ve & + ve & + ve & + ve & + ve & + ve \\
\hline Research \& Innovation & + ve & + ve & + ve & + ve & + ve & + ve & + ve & + ve \\
\hline Writing \& Publication & + ve & + ve & + ve & + ve & + ve & + ve & + ve & + ve \\
\hline Consultancy & + ve & + ve & + ve & + ve & + ve & + ve & + ve & + ve \\
\hline Services & + ve & + ve & + ve & + ve & + ve & + ve & + ve & + ve \\
\hline $\begin{array}{l}\text { DEPENDENTS } \\
\text { (NON- } \\
\text { ACADEMICS): } \\
\text { Professional } \\
\text { Competence }\end{array}$ & + ve & + ve & + ve & + ve & + ve & + ve & + ve & + ve \\
\hline $\begin{array}{l}\text { Strategic Leadership/ } \\
\text { Integrity/Confidentiality }\end{array}$ & + ve & + ve & + ve & + ve & + ve & + ve & + ve & + ve \\
\hline $\begin{array}{l}\text { Administrative } \\
\text { Procedures }\end{array}$ & + ve & + ve & + ve & + ve & + ve & + ve & + ve & + ve \\
\hline $\begin{array}{l}\text { Management Skills \& } \\
\text { Productivity }\end{array}$ & + ve & + ve & + ve & + ve & + ve & + ve & + ve & + ve \\
\hline $\begin{array}{l}\text { Initiation \& } \\
\text { Accountability }\end{array}$ & + ve & + ve & + ve & + ve & + ve & + ve & + ve & + ve \\
\hline Services & + ve & + ve & + ve & + ve & + ve & + ve & + ve & + ve \\
\hline
\end{tabular}

